\title{
SEXUAL STRUCTURE OF THE BLOODSUCKERS-FLIES (DIPTERA, HIPPOBOSCIDAE) POPULATION OF THE GENUS ORNITHOMYA LATREILLE, 1802 IN THE CENTRAL REGION AND NORTHERN PART OF RUSSIA
}

(C) 2019

Pavlov Aleksandr Vladimirovich, biology teacher

Muromtsevskaya Secondary School (Muromtsevo, Sudogodsky District, Vladimir Region, Russian Federation)

Bykov Yury Aleksandrovich, researcher of Science and Ecological Education Department

Meshchera National Park (Gus-Khrustalny, Vladimir Region, Russian Federation)

Matyukhin Aleksandr Vladimirovich, candidate of biological sciences, researcher of Bird Ringing Center A.N. Severtsov Institute of Ecology and Evolution of the Russian Academy of Sciences (Moscow, Russian Federation)

Abstract. In this paper the authors consider sex ratio in populations of the bloodsucker of the genus Ornithomya Latreille located in the Vladimir and Murmansk Regions. During the ringing of birds since 2014 we have been collecting the bloodsucker flies parasitizing on them. For just four years in the Vladimir Region we have examined 12515 birds, from which 94 females and 17 males of the bloodsucker Ornithomya avicularia L., 1758, as well as 142 females and 37 males Ornithomya fringillina Curtis, 1836, were taken. On the territory of the Murmansk Region in 2016 and 2017465 females and 91 males of Ornithomya chloropus Bergot, 1901 were collected from birds. As a result of our research we obtained and summarized original material on the composition of the sexual structure of the population in bloodsucker flies (Diptera, Hippoboscidae) belonging to the genus Ornithomya Latreille, 1802. Females dominate males in Ornithomya avicularia, Ornithomya chloropus and Ornithomya fringillina in populations located on the territory of the Vladimir and Murmansk Regions of the Russian Federation. The study of seasonal changes in the sexual structure of the above species showed a gradual decrease in the number of male individuals during the season.

Keywords: gender structure of population; males; females; bloodsucker flies; bird parasites; hematophagous; Vladimir Region; Murmansk Region; Meshchera National Park; genus Ornithomya; Ornithomya avicularia; Ornithomya chloropus; Ornithomya fringillina; Diptera; Hippoboscidae; bird ringing; frequency of bloodsucker occurrence; seasonal dynamics of bloodsucker number.

УДК 574.2

DOI 10.24411/2309-4370-2019-11115

Статья поступила в редакцию 21.12.2018

\section{АКТИВНОСТЬ КАТАЛАЗЫ ТРАВЯНИСТЫХ РАСТЕНИЙ В УСЛОВИЯХ ЗАГРЯЗНЕНИЯ ГОРОДСКОЙ СРЕДЫ}

(C) 2019

Петухов Александр Сергеевич, магистрант кафедры органической и экологической химии

Хритохин Николай Александрович, кандидат химических наук,

профессор кафедры неорганической и физической химии

Кремлева Татьяна Анатольевна, доктор химических наук,

заведующий кафедрой органической и экологической химии

Петухова Галина Александровна, доктор биологических наук, профессор кафедры экологии и генетики

Тюменский государственный университет (г. Тюмень, Российская Федерация)

Аннотация. Поступающие в клетки растений поллютанты способны вызывать биохимические нарушения, в том числе перекисное окисление липидов, что приводит к изменению активности антиоксидантной системы. Поддержание окислительно-восстановительного равновесия в клетках является необходимым условием выживания растений в условиях антропогенного загрязнения. Целью работы было изучение активности каталазы в мятлике луговом, мышином горошке, клевере красном, мать-и-мачехе и ромашке вблизи различных промышленных предприятий г. Тюмени. Растения были собраны вблизи автотрассы, а также в районах аккумуляторного, моторостроительного, нефтеперерабатывающего и металлургического предприятий. Изменение активности каталазы в клетках растений оказалось видоспецифичным. В клетках мятлика лугового и мышиного горошка наблюдалось снижение активности каталазы, а в мать-и-мачехе, клевере красном и ромашке - как снижение, так и активация фермента. Поллютанты всех изученных предприятий оказывали в той или иной степени влияние на активность каталазы, однако наибольший эффект был зарегистрирован вблизи металлургического завода, что, вероятно, связано с высоким поступлением тяжелых металлов в растения. Наименьшее воздействие на активность каталазы по сравнению с контролем было обнаружено вблизи автотрассы.

Ключевые слова: каталаза; загрязнение окружающей среды; городская среда; растения; тяжелые металлы; мятлик луговой; мышиный горошек; клевер красный; мать-и-мачеха; ромашка; перекисное окисление липидов; антиоксиданты; ферменты; видоспецифичность; ответная реакция организма.

\section{Введение}

Произрастание растений в неблагоприятных условиях среды оказывает влияние прежде всего на их биохимический статус, что проявляется в изменении жизнедеятельности. Поступающие в клетки организма поллютанты могут накапливаться и вызывать различные биохимические нарушения [1]. Одним из наиболее важных процессов повреждения клеток на 
Петухов А.С., Хритохин Н.А., Кремлева Т.А., Петухова Г.А.

биохимическом уровне является перекисное окисление липидов (ПОЛ) [2].

Высокие концентрации активных форм кислорода (АФК) - гидроксильного радикала $\left(\mathrm{OH}^{*}\right)$, свободных радикалов $\mathrm{HO}_{2}^{*}, \mathrm{RO}^{*}, \mathrm{ROO}^{*}$, супероксидного анион радикала $\left(\mathrm{O}_{2}{ }^{*-}\right)$, синглетной формы кислорода $\left({ }^{1} \mathrm{O}_{2}\right)$ и перекиси водорода $\left(\mathrm{H}_{2} \mathrm{O}_{2}\right)$ вызывают перекисное окисление липидов [3]. В отсутствие стресса содержание АФК в организме невысоки: концентрация гидроперекисного радикала составляет менее $10^{-}$ ${ }^{11} \mathrm{M}$, содержание супероксида составляет примерно $10^{-11} \mathrm{M}$, а пероксида водорода $-10^{-8} \mathrm{M}$ [4].

АФК обладают высокой активностью и поэтому способны вызывать нарушение структуры основных биополимеров: белков, нуклеиновых кислот, углеводов и липидов [5]. Основная опасность процессов ПОЛ состоит в увеличении проницаемости клеточных мембран для ионов водорода, что может снизить активность синтеза АТФ в клетке и вызвать энергетический голод. Кроме того, развитие ПОЛ может привести к электрическому пробою клеточной мембраны и полной потере ею барьерной функции [4; 6].

Для нейтрализации АФК и блокирования процессов ПОЛ в клетках растений действуют антиоксиданты. Антиоксидантная система состоит из неферментных компонентов, таких как флавоноиды и фенолы, пролин, глутатион, аскорбиновая кислота, а также ферментных антиоксидантов: каталазы, супероксиддисмутазы и пероксидазы [7].

Каталаза и пероксидаза утилизируют перекись водорода и тем самым являются передовой линией защиты от токсического действия АФК. Они сводят концентрацию супероксид аниона и пероксида водорода в клетке до минимума и не позволяют им реагировать с образованием гидроксильного аниона [8]. Каталаза является хромопротеидом и имеет в качестве небелковой группы окисленный гем. Одна молекула каталазы способна вызвать разрушение $6 \times 10^{6}$ молекул $\mathrm{H}_{2} \mathrm{O}_{2}$ в секунду. Однако каталаза имеет низкое сродство к перекиси водорода, из-за этого начинает функционировать только при высоком ее содержании в клетке [9].

Различными исследователями проводилось изучение влияния тяжелых металлов на активность каталазы в растениях [8-17], в том числе с использованием промышленных сточных вод [18], что доказало эффективность применения каталазы в качестве индикатора неблагоприятных условий среды. Кроме того, проводилось исследование влияния засоления почвы на активность каталазы в растениях [19]. Важность функционирования каталазы в адаптации к условиям окружающей среды было выявлено при воздействии $\mathrm{Pb}^{2+}$ и $\mathrm{Cd}^{2+}$ на Solanum lycopersicum: активность каталазы росла, несмотря на снижающуюся экспрессию соответствующих генов [20].

Однако научных работ, посвященных исследованию активности антиоксидантных ферментов в клетках растений в условиях загрязнения городской среды, которая характеризуется высокой распространенностью тяжелых металлов и других токсикантов, немного. В связи с этим целью работы стало изучение активности каталазы в различных травянистых растениях, произрастающих вблизи промышленных предприятий г. Тюмени.

\section{Материал и методика исследований}

Материал для исследования отобран в конце июля в течение 3-4 дней в различных районах города Тюмени на следующих участках:

1) контроль - луг на удалении 5 километров от антропогенных источников (участок обозначен на рисунках в статье под номером 1);

2) автотрасса Тюмень - Омск - район п. Винзили, 30 км от г. Тюмени, интенсивность движения 700 машин в час (в середине дня), удаление от автотрассы не более 30 метров (участок обозначен на рисунках в статье под номером 2);

3) УГМК - г. Тюмень, участок на удалении 200 м от предприятия «УГМК-Сталь» вблизи автотрассы (участок обозначен на рисунках в статье под номером 3);

4) УГМК 2 - г. Тюмень, участок на удалении 50 м от предприятия «УГМК-Сталь» (участок обозначен на рисунках в статье под номером 4);

5) НП3 - г. Тюмень, участок на удалении 200 м от предприятия Антипинского нефтеперерабатывающего завода (участок обозначен на рисунках в статье под номером 5);

6) Моторостроители - г. Тюмень, участок на удалении 200 м от предприятия «Тюменские моторостроители» (участок обозначен на рисунках в статье под номером 6);

7) район аккумуляторного завода, г. Тюмень, участок на удалении 200 метров от предприятия (участок обозначен на рисунках в статье под номером 7).

На каждом участке была срезана надземная часть растений с 5 площадок. Были отобраны 5 видов растений: клевер красный (Trifolium rubens), мать-имачеха (Tussilago farfara), мышиный горошек (Vicia cracca), мятлик луговой (Poa pratensis), ромашка (Matricaria chamomilla). На участке № 6 ромашка не обнаружена. Площадь участков составляла не менее $100 \mathrm{~m}^{2}$. На каждом участке было собрано не менее 100 растений каждого вида. Отбирали усредненную пробу методом квартования. Анализ активности каталазы в растениях проводился с помощью спектрофотометрии путем проведения цветной реакции между перекисью водорода и молибдатом аммония с измерением оптической плотности продуктов реакции на $\lambda=470$ нм [21].

Полученные результаты подвергнуты стандартной статистической обработке с использованием программного обеспечения Statistica 10. Рассчитывали среднее значение, стандартную ошибку, сравнение выборок проводили по t-критерию с уровнем доверительной вероятности $\mathrm{P} \leq 0,05$.

\section{Результаты исследований и их обсуждение}

Изменение активности каталазы в клетках растений в условиях городской среды оказалось видоспецифичным (рис. 1-5).

В клетках мятлика и мышиного горошка наблюдалась тенденция к снижению активности каталазы. Активность каталазы в клетках мятлика была подавлена на участках УГМК 2 и аккумуляторного завода в 2 раза по сравнению с контролем (рис. 1). Наибольшее снижение активности фермента было отмечено на участке моторостроительного завода (более чем в 7 раз). В то же время вблизи автотрассы, а также у растений из районов УГМК и НПЗ активность каталазы оставалась на уровне контроля. 


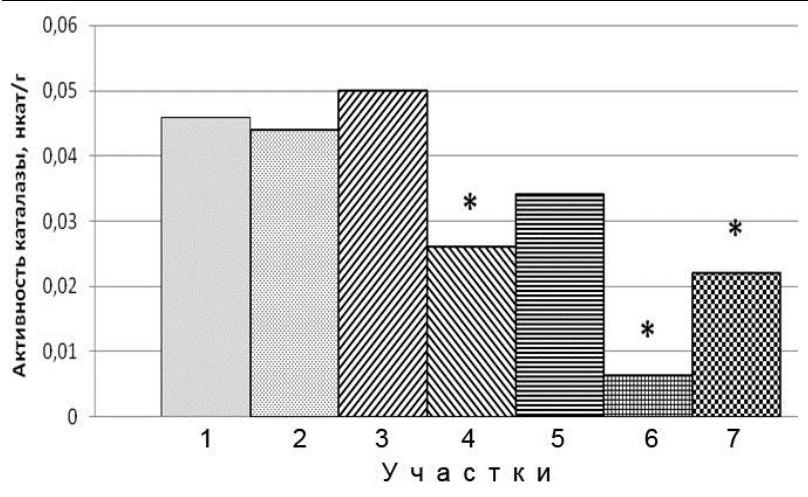

Рисунок 1 - Активность каталазы в клетках мятлика лугового из районов исследования.

* - статистически достоверные различия между контролем и вариантом опыта (при $\mathrm{P} \leq 0,05)$

Активность каталазы в клетках мышиного горошка только вблизи автотрассы также не отличалась от контроля (рис. 2). Однако в целом для мышиного горошка наблюдалось большее количество отклонений от контроля, по сравнению с мятликом. Активность каталазы на участках УГМК, УГМК 2, Моторостроители, аккумуляторный завод, НПЗ была снижена на $30-40 \%$.

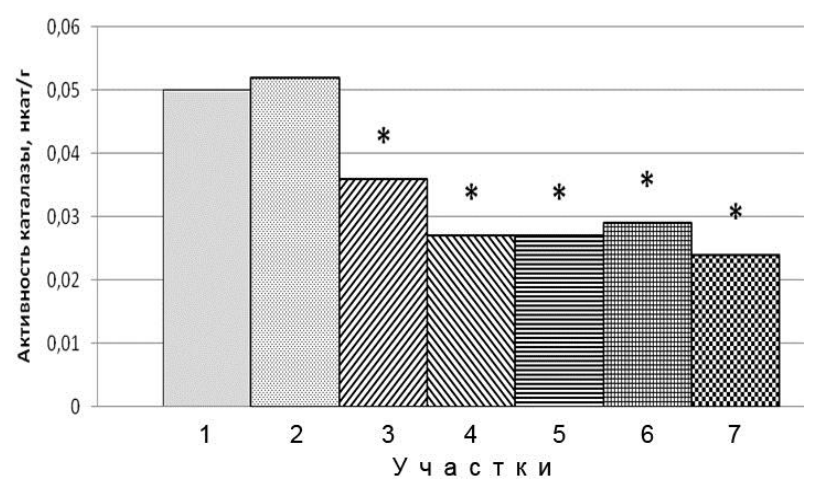

Рисунок 2 - Активность каталазы в клетках мышиного горошка из районов исследования

Снижение активности каталазы может быть вызвано как повреждением структуры фермента, так и нарушением пути биосинтеза каталазы. Поступающие в клетки растений токсиканты могут связываться c $-\mathrm{SH},-\mathrm{NH}_{2},-\mathrm{COOH}$ группами аминокислот, входящих в состав фермента, что может привести к подавлению ферментативной активности. Кроме того, возможно опосредованное повреждение структуры фермента тяжелыми металлами и другими поллютантами, способными вызывать ПОЛ. Образующиеся активные формы кислорода (пероксид водорода, гидроксил радикал, супероксид анион, свободные радикалы, синглентая форма кислорода), которые могут окислить углеводородные цепи аминокислот в составе фермента до гидроперекисей, малонового диальдегида и оснований Шиффа. В литературе сообщалось об отрицательном влиянии $\mathrm{Cd}$ на активность каталазы в проростках пшеницы, что также сопровождалось ростом концентрации продуктов перекисного окисления липидов [9]. Снижение активности каталазы в ответ на загрязнении среды кадмием в клетках кресс-салата также было выявлено в исследовании О.А. Науменко с соавторами [13].

Если поступающие в клетку токсиканты имеют близкий ионный радиус к радиусу иона $\mathrm{Fe}^{2+}$ и необходимое сродство к образованию порфириновых комплексов (например, $\mathrm{Cu}^{2+}$ ), то также возможно замещение иона $\mathrm{Fe}^{2+}$ в составе гема - простетической группы каталазы, что, безусловно, скажется на ферментативной активности и, скорее всего, приведет к ее подавлению. Все вышеописанное может быть применено и к ферментам, участвующим в биосинтезе каталазы, повреждение их структуры и подавление их активности скажется на снижении концентрации каталазы в клетке.

Картина по изменению активности каталазы в объектах исследования: мать-и-мачехе, ромашке и красном клевере - оказалась неоднозначная. Для этих растений видоспецифичность оказалась еще более выраженной. Так, вблизи автотрассы активность каталазы в клетках мать-и-мачехи была повышена почти в 2,5 раза (рис. 3), у ромашки - в 1,4 раза (рис. 4), а в клетках клевера красного осталась на контрольном уровне (рис. 5). Аналогичный результат был получен и для участка УГМК 2: в клетках матьи-мачехи и ромашки активность каталазы была увеличена в 2,5 раза, а в клетках клевера красного снижена почти в 1,7 раза.

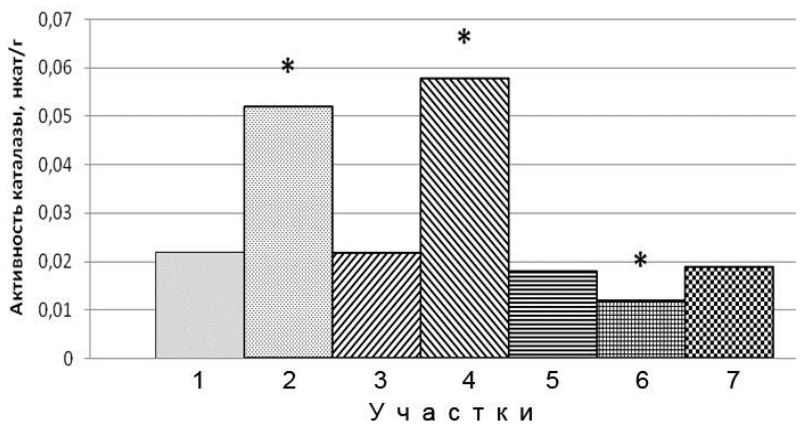

Рисунок 3 - Активность каталазы в клетках мать-и-мачехи из районов исследования

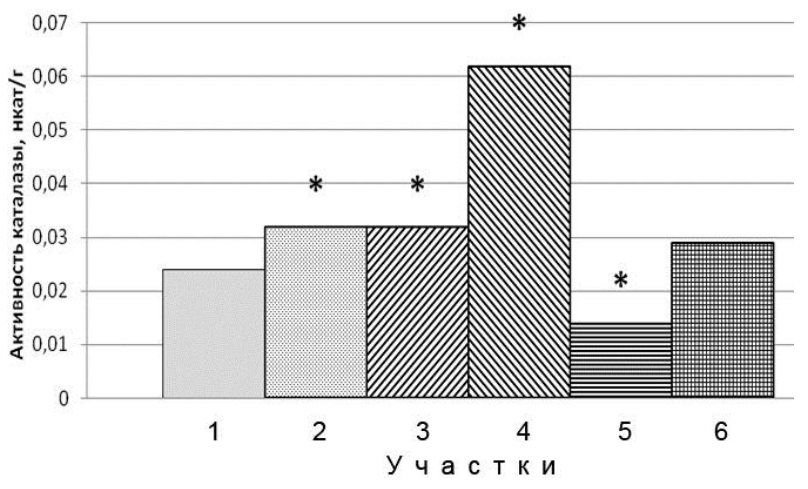

Рисунок 4 - Активность каталазы

в клетках ромашки из районов исследования

С другой стороны, для клевера красного также была отмечена резкая активация каталазы на участке НП3 в 4,5 раза (рис. 5), что, однако, было нехарактерно для мать-и-мачехи (активность каталазы была на уровне контроля) и ромашки (активность каталазы снижена на 40\%). Резкое повышение активности каталазы в клетках клевера красного было также выявлено на участке УГМК. В клетках ромашки также наблюдалось повышение активности каталазы на этом участке на $30 \%$, в то время как для мать-имачехи ферментативная активность осталась без изменений. Кроме того, для клевера красного наблюдалось повышение активности каталазы вблизи аккумуляторного завода, что не было отмечено для других изученных растений. Неоднозначное воздействие поллютантов на активность каталазы было вы- 
Петухов А.С., Хритохин Н.А., Кремлева Т.А., Петухова Г.А.

явлено в исследовании Л.А. Кобринец [12] на примеpe Lupinus luteus при внесении свинца: активность каталазы в корнях снижалась, а в зеленой части увеличивалась.

Повышение активности каталазы на участке УГМК 2 по сравнению с участком УГМК (увеличение в 2 раза) в клетках ромашки может быть связано с более высоким уровнем поступлением поллютантов в связи с непосредственной близостью к предприятию. Ранее также была обнаружена резкая активация каталазы в клетках Raphanus sativus при действии высоких доз кадмия (50 ПДК) [16].

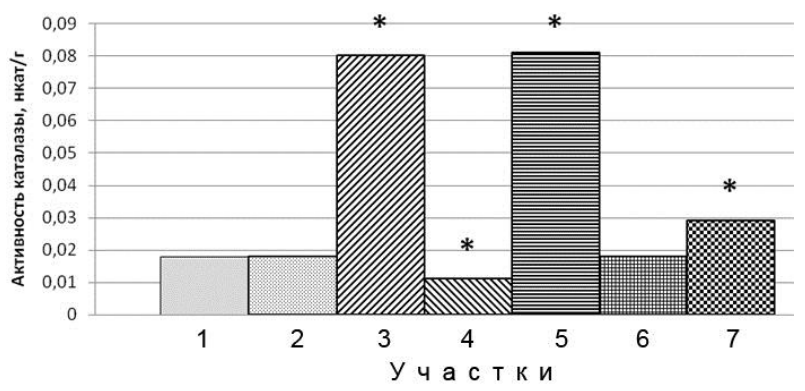

Рисунок 5 - Активность каталазы

в клетках клевера красного из районов исследования

Видоспецифическая реакция растений (в частности активности каталазы) на загрязнение городской среды может быть связана с различной антиоксидантной активностью растений, особенностями биосинтеза ферментов, в том числе антиоксидантных, а также с разными механизмами генетического регулирования в условиях стресса, то есть различной устойчивостью растений. Все вышеназванные особенности биохимии и генетики растений могут обуславливать снижение активности или, наоборот, активацию каталазы на одном и том же участке у разных видов растений. По всей видимости, одни и те же концентрации поступающих в клетку загрязнителей вблизи того же самого промышленного предприятия может оказывать различный эффект на активность каталазы, в зависимости от устойчивости растений. Из литературы известно, что полив растений растворами, содержащими $\mathrm{Pb}^{2+}, \mathrm{Cd}^{2+}$ и $\mathrm{Hg}^{2+}$, практически не сказывался на активности каталазы в Bruguiera gymnorrhiza, в то время как использование этих же растворов приводило к увеличению активности фермента в Kandelia candel [14]. Специфичность изменения активности каталазы также была выявлена при анализе лебеды садовой (Artiplex hortensis): в лебеде садовой зеленой при выращивании в почве, загрязненной $\mathrm{Ni}, \mathrm{Pb}, \mathrm{Cu}$ и $\mathrm{Zn}$, наблюдалось увеличение активности каталазы, в то время как в лебеде садовой красной активность каталазы оставалась на уровне контроля [10]. Рост Eletrigia repens в почве, загрязненной $\mathrm{Cd}$, приводил к увеличению активности каталазы в клетках корня более чем в 2 раза, в то время как активность фермента в листьях оставалась без изменений [17].

Повышение активности каталазы может быть обусловлено включением защитных механизмов в клетке, диктующих утилизацию генерирующегося в ходе стресса пероксида водорода. Ранее в исследовании С.В. Мурзаевой [18] было обнаружено повышение активности каталазы на $30 \%$ в пшенице, обработанной неочищенными сточными водами, содержащими высокие концентрации тяжелых металлов.
Увеличение активности каталазы также наблюдалось в Zea mays при поливе раствором хлорида кадмия, причем этот эффект усиливался по мере увеличения концентрации токсиканта, что указывает на роль каталазы в борьбе с биохимическими нарушениями, вызванными при действии кадмия [15]. Аналогичный результат был получен при обработке Brassica napus нитратом свинца [8], а также у Jatropha curcas при действии $\mathrm{Pb}, \mathrm{Cd}$ и $\mathrm{Cr}$ [11]. Рост Phaseolusvulgaris в условиях засоления $\mathrm{NaCl}$ сопровождался увеличением активности аскорбатпероксидазы, глутатионредуктазы, а также каталазы [19]. Кроме того, рост активности каталазы вблизи металлургического предприятия может быть связан с поступлением в клетку $\mathrm{Fe}$, входящего в состав гема, необходимого для работы каталазы. В ранее проведенном нами исследовании была обнаружена активация каталазы в клетках овса при модельном загрязнении органогенной почвы Fe и $\mathrm{Mn}$ [22]. Усиление активности пероксидазы может быть связано с изменением ее компонентного состава. Ферменты находятся в клетках как в свободном, так и в связанном состоянии, а при действии стресса происходит увеличение доли их свободных форм из-за освобождения связанных [16].

В связи с наблюдаемой видоспецифической ответной реакцией растений сложно выделить те участки, загрязнители которых оказывали наибольшее влияние на активность каталазы. Однако в целом в первую очередь стоит отметить металлургический завод: участок УГМК 2 и в меньшей степени участок УГМК. Участок УГМК 2 оказался единственным из всех исследуемых районов, на котором было обнаружено изменение активности каталазы у всех изученных растений. Наименьший эффект на активность каталазы был зафиксирован в районе автотрассы, а также аккумуляторного завода. Полученный эффект может быть объяснен вышеописанным поступлением $\mathrm{Fe}$ в клетки растений, которое непосредственно влияет на активность каталазы, как за счет возможной генерации перекисного окисления липидов, так и за счет включения в состав порфириновых комплексов. Наименьшее, по сравнению с другими участками, воздействие автотрассы на активность каталазы связано с отсутствием вблизи промышленных предприятий, в то время как все предприятия находятся вблизи различных автодорог.

\section{Заключение}

Таким образом, анализ активности каталазы в растениях вблизи различных промышленных предприятий показал видоспецифическую ответную реакцию. В клетках мятлика и мышиного горошка наблюдалась тенденция к снижению активности каталазы, в то время как в клетках мать-и-мачехи, клевера красного и ромашки наблюдалось как снижение активности фермента, так и активация каталазы. Видоспецифичность может быть вызвана различным синтезом и функционированием антиоксидантных систем в клетках, а также особенностями генетического аппарата. Было показано, что поллютанты всех изученных предприятий в той или иной степени вызывают стресс для растений, что приводит к изменению активности каталазы. Однако наибольшее влияние на активность каталазы оказал металлургический завод, что может быть вызвано сродством поступающего в клетки растений железа с каталазой. 


\section{Список литературы:}

1. Титов А.Ф., Казнина Н.М., Таланова В.В. Тяжелые металлы и растения. Петрозаводск: Карельский научный центр РАН, 2014. 194 с.

2. Skorzynska-Polit E. Lipid peroxidation on plant cells, its physiological role and changes under heavy metal stress // Acta Societatis Botanicorum Poloniae. 2007. № 74. P. 49-54.

3. Чеснокова Н.П., Понукалина Е.В., Бизенкова М.Н. Механизмы структурной и функциональной дезорганизации биосистем под влиянием свободных радикалов // Фундаментальные исследования. 2007. № 4. С. 110-121.

4. Blokhina O., Virolainen E., Fagerstedt K.V. Antioxidants, oxidative stress and oxygen deprivation stress: a review // Annals of Botany. 2001. № 91. P. 179-194.

5. Anjum N.A., Sofo A., Scopa A., Roychoudhury A. Lipids and proteins - major targets of oxidative modifications in abiotic stressed plants // Environmental Science and Pollution Research. 2015. № 22. P. 4099-4121.

6. Владимиров Ю.А. Свободнорадикальное окисление липидов и физические свойства липидного слоя биологических мембран // Биофизика. 1987. Т. 32, № 5. C. 830-844.

7. Gratao P.L., Polle A., Lea P.J., Azevedo R.A. Making the life of heavy metal-stressed plants a little easier // Functional Plant Biology. 2005. Vol. 32. P. 481-494.

8. Hosseini R.H., Khanlarian M., Ghorbanli M. Effect of lead on germination, growth and activity of catalase and peroxidase enzyme in root and shoot of two cultivars of Brassica napus L. // Journal of Biological Sciences. 2007. № 7. P. 592-598.

9. Колесниченко В.В., Колесниченко А.В. Изучение влияния высокой концентрации кадмия на функционирование антиоксидантных систем этиолированных проростков пшеницы разной длины // Journal of Stress Physiology and Biochemistry. 2011. Vol. 7, № 3. P. 212-221.

10. Kachout S.S., Ben Mansoura A., Leclerc J.C., Mechergui R., Rejeb M.N., Ouerghi Z. Effects of heavy metals on antioxidant activities of Artiplex hortensis and A. rosea // Journal of Food, Agriculture and Environment. 2009. Vol. 7. P. 938-945.

11. Devi Chinmayee M., Anu M.S., Mahesh B., Mary Sheeba A., Mini I., Swapna T.S. A comparative study of heavy metal accumulation and antioxidant responses in Jatropha curcas L. // Journal of Environmental Science, Toxicology and Food Technology. 2014. Vol. 8, № 7. P. 58-67.

12. Кобринец Л.А. Изменение активности ферментов антиоксидантной системы у проростков люпина, вызванной действием соединений свинца //
Вестник Брестского государственного технического университета. 2012. № 2. С. 86-89.

13. Науменко О.А., Саблина Е.В., Кабышева М.И., Костенецкая Е.А. Исследование механизма повреждающего действия избыточных концентраций кадмия на состояние антиоксидантных ферментов кресссалата // Вестник Оренбургского государственного университета. 2013. Т. 159, № 10. С. 205-207.

14. Zhang F.Q., Wang Y.S., Lou Z.P., Dong J.D. Effect of heavy metal stress on antioxidant enzymes and lipid peroxidation in leaves and roots of two mangrove plant seedlings (Kandelia candel and Bruguiera gymnorrhiza) // Chemosphere. 2007. Vol. 67. P. 44-50.

15. Anjum S.A., Tanveer M., Hussain S., Bao M., Wang L., Khan I. Cadmium toxicity in maize (Zea mays L.): consequences on antioxidatie systems, reactive oxygen species and cadmium accumulation // Environmental Science and Pollution Research. 2015. № 21. P. 1702217030.

16. Еремченко О.3., Кусакина М.Г., Голева Т.Н. Активность компонентов антиоксидантной защиты $R a$ phanus sativus L. при выращивании на почве, загрязненной сульфатами свинца и кадмия // Вестник Пермского университета. Биология. 2014. № 1. С. 10-16.

17. Казнина Н.М., Батова Ю.В., Титов А.Ф., Лайдинен Г.Ф. Роль отдельных компонентов антиоксидантной системы в адаптации растения Eletrigia repens (L.) Nevski к кадмию // Труды Карельского научного центра РАН. 2016. № 11. С. 17-26.

18. Мурзаева С.В. Накопление тяжелых металлов и активность антиоксидантных ферментов в пшенице при воздействии сточных вод // Известия Самарского научного центра Российской академии наук. 2002. T. 4, № 2. С. 260-269.

19. Ясар Ф., Элиальтиглу С., Ильдис К. Действие засоления на антиокислительные защитные системы, перекисное окисление липидов и содержание хлорофилла в листьях фасоли // Физиология растений. 2008. T. 55, № 6. C. 869-873.

20. Buyuk I., Gunduzer E., Kandemir I., CansaranDuman D. Effects of lead and cadmium elements on lipid peroxidation, catalase enzyme activity and catalase gene expression profile in tomato plants // Journal of Agricultural Sciences. 2016. Vol. 22. P. 539-547.

21. Королюк М.А., Иванова Л.И., Майорова Н.О., Токарев В.Е. Метод определения активности каталазы // Лабораторное дело. 1988. № 1. С. 16.

22. Petukhov A.S., Khritokhin N.A., Petukhova G.A., Kudryavtsev A.A. Biochemical response of the oat to accumulation of iron and manganese // Pollution Research. 2017. Vol. 36, № 1. P. 1-7.

\section{CATALASE ACTIVITY OF HERBS IN CONDITIONS OF URBAN ENVIRONMENT POLLUTION} (C) 2019

Petukhov Alexander Sergeevich, master student of Organic and Ecological Chemistry Department

Khritokhin Nikolay Aleksandrovich, candidate of chemical sciences, professor of Inorganic and Physical Chemistry Department

Kremleva Tatyana Anatolyevna, doctor of chemical sciences, head of Organic and Ecological Chemistry Department

Petukhova Galina Aleksandrovna, doctor of biological sciences, professor of Ecology and Genetics Department Tyumen State University (Tyumen, Russian Federation)

Abstract. Pollutants entering plants cells are able to cause biochemical malfunction, including lipid peroxidation, which leads to the change in antioxidant system activity. Sustaining redox balance in cells is a required condition of plants survival in conditions of anthropogenic pollution. The goal of this research was the investigation of catalase 
activity in meadow grass, wild vetch, red clover, coltsfoot and chamomile near various factories of Tyumen. Plants were gathered near the highway as well as close to the metallurgical plant, engine factory, oil refinery and accumulator plants. The change in catalase activity in the cells of plants turned out to be species-specific. The decrease in catalase activity was observed in the meadow grass and wild vetch cells, while in coltsfoot, red clover and chamomile both decrease and increase in enzyme activity was obtained. Pollutants from all the examined factories affected more or less on the catalase activity, but the greatest effect was registered near the metallurgical factory, that probably related to high heavy metal concentration in plants. The lowest effect on catalase activity, compared to control, was observed near the highway.

Keywords: catalase; environmental contamination; urban environment; plants; heavy metals; meadow grass; wild vetch; red clover; coltsfoot; chamomile; lipid peroxidation; antioxidants; enzymes; species-specificity; organism response.

УДК 574.24

DOI 10.24411/2309-4370-2019-11116

Статья поступила в редакцию 13.12.2018

\section{СРАВНИТЕЛЬНЫЙ ЭКОЛОГО-МОРФОЛОГИЧЕСКИЙ АНАЛИЗ ЛЕТАТЕЛЬНОГО АППАРАТА ПТИЦ СЕМЕЙСТВА ВРАНОВЫЕ (CORVIDAЕ)}

(C) 2019

Репин Денис Владимирович, кандидат биологических наук, доцент кафедры биоэкологии и химии Чувашский государственный педагогический университет им. И.Я. Яковлева (2. Чебоксары, Российская Федерация)

Репина Надежда Васильевна, кандидат биологических наук, преподаватель

Чебоксарский кооперативный техникум Чувашпотребсоюза (г. Чебоксары, Российская Федерация)

Аннотация. В данной статье приводится сравнительный эколого-морфологический анализ летательного аппарата массовых видов птиц семейства Врановые: грача, галки, серой вороны, сороки. Данные виды птиц обладают разным характером полета и разной летательной активностью - среди них есть и оседлые, и перелетный виды. Исследования эколого-морфологических особенностей летательного аппарата грача, галки, серой вороны и сороки проводились на территории Чувашской Республики в осенний и весенний периоды в течение 2014-2018 годов. В статье описаны полевые наблюдения за характером полета изучаемых видов и приведены результаты морфометрических измерений. Для исследований использовались следующие морфологические параметры птиц: масса тела, длина тела, длина хвоста, длина крыла, размах крыльев, ширина крыла. Для изучения развития летательной мускулатуры птиц определялись массы подключичной и грудной мышц и индексы отношения этих параметров к массе тела и между собой. Данные показатели использовались для вычисления ряда индексов. Проведенные исследования летательного аппарата птиц выявили межсезонные различия по некоторым параметрам, связанным с массой тела. Кроме того, определены видовые особенности строения летательного аппарата рассмотренных птиц семейства Врановые, связанные с характером и скоростью полета, длительностью миграции.

Ключевые слова: Чувашская Республика; врановые; грач; галка; серая ворона; сорока; летательный аппарат; полет; весовая нагрузка на крылья; весовая нагрузка на крылья и сложенный хвост; весовая нагрузка на крылья и расправленный хвост; размах крыльев; ширина крыла; удлинение крыла; площадь крыла; подключичная мышца; грудная мышца; оседлые птицы; перелетные птицы.

\section{Введение}

За последние годы в России существенно вырос интерес к исследованию экологических и морфологических особенностей массовых видов птиц семейства Врановые [1-6]. Возможно, это связано с существенным ростом численности популяций данных видов, которые составляют значительную долю населения птиц, особенно в антропогенных ландшафтах, а также с увеличением их биоценотического и хозяйственного значения.

В биологических науках большое значение имеет сравнение морфологических особенностей отдельных видов или популяций организмов, относимых к одной систематической категории $[7 ; 8]$. При изучении вариабельности морфологических признаков у отдельных видов можно получить довольно подробное представление о биологических особенностях исследуемой группы организмов. При этом на основе эколого-морфологических различий между популяциями одного вида или отдельными видами можно определить характер влияния условий среды обитания на организмы [9; 10]. Мускулатура птиц отличается сложной структурой, которая зависит от силовых, скоростных показателей и выполняемых функций. Физиологические нагрузки на разные отделы летательной мускулатуры птиц влияют на форму мышц, их архитектонику [11, с. 202].

В современных эколого-морфологических исследованиях изучению полета птиц, морфологическим особенностям летательного аппарата и их влиянию на характер полета уделено мало внимания. Основные результаты исследования летательного аппарата птиц описаны в работах Н.А. Гладкова; В.Ф. Сыча; Л.В. Фоменко; I.C. George, A.I. Berger; B. Jenner, T. Tomek, Z. Bocheński [7; 11-14]. Описаны исследования роста отделов скелета крыла у птенцов врановых в гнездовой период [15, с. 122-125]. В то же время в условиях Чувашии эколого-морфологические исследования летательного аппарата врановых птиц не проводились. 